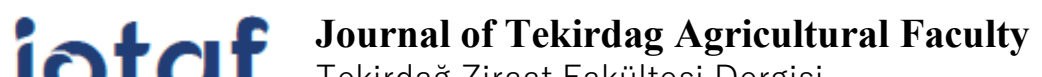 \\ Tekirdağ Ziraat Fakültesi Dergisi
}

\section{Mekanik Hasar Düzeyinin Domatesin Solunum ve Kuru Madde Miktarı Üzerine Etkisi ${ }^{*}$}

The Effect of Mechanical Damage Level on the Amount of Respiration and Dry Matter of

Tomato

\author{
Samet ÖZTÜRK ${ }^{1}$, Türkan AKTAŞ²*
}

\section{Özet}

$\mathrm{Bu}$ araştırmanın temel amacı, domates meyvesinde ortam sıcaklığı ve hasat sonrası oluşan mekanik hasar düzeylerine bağlı solunum oranını ve kuru madde kayıplarını belirlemektir. Bu amaçla statik bir ölçme yöntemi kullanılarak hasara ve ortam sıcaklığına bağlı olarak $\mathrm{CO}_{2}$ üretim miktarları belirlenmiştir. Ayrıca denemeler sonucunda üründe oluşan toplam ağırlık kayıpları ve meyve eti sertliğinde oluşan değişimler de saptanmıştır. Araştırmada bitkisel materyal olarak hasat sonrasında solunum hızında yükselme olan (klimakterik) ürünlerden birisi olan domates kullanılmıştır. Denemeler 2 farklı ortam sıcaklığı $(2 \pm 2,22 \pm 2)$ ve 5 farklı zedelenme düzeyi (sağlam, $1 \mathrm{~cm}^{2}$ alanında kabuğu soyulmuş, 10,20,30 cm yükseklikten darbe testi uygulanmış örnekler) koşullarında gerçekleştirilmiştir. Araştırma sonuçlarına göre çarptırma yüksekliği arttıkça zedelenme hacimleri artmıştır. Hem oda sıcaklığı koşulunda hem de soğuk hava koşulundaki hasarsız domates örneklerinin $\mathrm{CO}_{2}$ üretim miktarları, solunum oranları ve kuru madde kaybı diğer örneklerinkine kıyasla oldukça düşük olduğu saptanmıştır. Ortam sıcaklığının yükselmesi ile bu değerlerde de oldukça büyük bir artış olmuştur. Kabuğu soyulmuş olan örneklerin hem oda koşullarında hem de soğuk ortam koşullarında solunum oranlarının ve kuru madde kayıplarının diğer örneklerinkine kıyasla çok daha yüksek olduğu bunu sırasıyla $30 \mathrm{~cm}$ yükseklikten, $20 \mathrm{~cm}$ yükseklikten ve $10 \mathrm{~cm}$ yükseklikten darbe testi uygulanmış örneklerin takip ettiği saptanmıştır. Ağırlık kayıpları göz önünde bulundurulduğunda, tüm deneme materyallerinde ölçümler öncesi ve sonrası arasında en büyük ağırlık kayıplarının da diğer tüm sonuçlara paralel olarak kabuğu soyulan meyvelerde olduğu görülmektedir. Hem ortam sıcaklığının hem de zedelenme düzeylerinin solunum oranı üzerine etkilerinin 0,01 düzeyinde önemli olduğu saptanmıştır. Mekanik hasar uygulanan ve kabuğu soyulan ürünlerde meyve eti sertliğinin önemli oranda düştüğü saptanmıştır.

Anahtar Kelimeler: Mekanik zedelenme, Domates, Solunum oranı, $\mathrm{CO}_{2}$ üretimi, Kuru madde kayb1

\footnotetext{
2*Sorumlu Yazar/Corresponding Author: Türkan Aktaş, Namık Kemal Üniversitesi, Ziraat Fakültesi, Biyosistem Mühendisliği Bölümü, Tekirdağ, Türkiye. Email: taktas@nku.edu.tr (D) OrcID: 0000-0001-9977-859X

${ }^{1}$ Samet Öztürk, İpsala İlçe Tarım Müdürlüğü, İpsala, Edirne, Türkiye. E-mail: sametozturk@live.com (DD OrcID: 0000-0002-2007-861X. Atıf/Citation: Öztürk, S., Aktaş, T. Mekanik Hasar Düzeyinin Domatesin Solunum ve Kuru Madde Miktarı Üzerine Etkisi. Tekirdă̆ Ziraat Fakültesi Dergisi, 18 (1), 125-137.

* Bu çalışma Samet ÖZTÜRK' ün yüksek lisans tezinin bir kısmından türetilmiștir.

CBu çalışma Tekirdağ Namık Kemal Üniversitesi tarafından Creative Commons Lisansı (https://creativecommons.org/licenses/by-nc/4.0/) kapsamında yayınlanmıştır. Tekirdağ 2021
} 


\begin{abstract}
Basic aims of this research are determination of effects of medium temperature and mechanical damage that can be occurred due to postharvest processes of $\mathrm{CO}_{2}$ production amount of tomato by using static measurement method and calculation of respiration rate and dry matter loss by using $\mathrm{CO}_{2}$ production results and finally determination of necessary data to guess shelf life of these products. In addition to these, total weight losses and changes in hardness of fruits were also determined. As a plant material tomato that have high respiration rate after harvesting namely climateric fruits was selected. Experiments were performed in conditions that 2 different temperature $(2 \pm 2$, $22 \pm 2$ ) and 5 different damage levels (not damaged, peeled of skin into $1 \mathrm{~cm}^{2}$ area, impacted from 10,20 and 30 $\mathrm{cm}$ drop heights). According to results increasing of impact height increased bruising volume values. Either in room condition or in cool air condition $\mathrm{CO}_{2}$ production amount, respiration rate and dry matter loss values of undamaged tomato samples were found rather lower compared to peeled and damaged samples. Increasing of medium temperature highly increased these values. Either in room condition or in cool air condition respiration rate and dry matter loss of peeled samples were found rather higher compared to others. Samples impacted from $30 \mathrm{~cm}, 20 \mathrm{~cm}$ and $10 \mathrm{~cm}$ were followed this samples, respectively. Considering the weight losses, it is seen that the maximum weight losses in all tested materials before and after measurements were found in peeled fruits in parallel with all other results. It was determined that the effects of either medium temperature or bruising levels on the respiration rate were found significant at 0,01 importance level. It was determined that fruit hardness of peeled and impacted from different heights rather decreased after experiments.
\end{abstract}

Keywords: Mechanical damage, Tomato, Respiration rate, $\mathrm{CO}_{2}$ production, Dry matter loss 


\section{Giriş}

Mekanik hasat işlemleri sonrasında meyve ve sebzeler; ürünlerin çeşitli yüzeylere çarpması, kasalara boşaltma, paketleme hattında ilerleme ve paketleme zamanlarında çeşitli dinamik yüklenmelere maruz kalmaktadır. Bunun yanında depolama ve diğer hasat sonrası işlemler süresince diğer dinamik yüklenmeler söz konusu olabilmektedir. $\mathrm{Bu}$ tür ürünler özellikle meyve bahçelerinde yığın kasalarda ve özellikle depolama süresince uzun süre statik yüklenmelere de maruz kalmaktadır (Nelson ve Mohsenin, 1968).

Tarımsal ürünler hasat edildikten tüketiciye ulaşana kadarki zaman içerisinde, mekanik hasarın oluşumuna neden olan bir seri hasat sonrası işlemlere uğramaktadır. Meyve yüzeyinde oluşan renk koyulaşması, aşınma, kesilme veya delinme gibi mekanik hasarlar geri dönüşü mümkün olmayan hasar tipleridir ve hasat sonrası işlemler ile artan bir etkiye sahiptir. Öte yandan mekanik zedelenmeler, taze sebze ve meyvelerin çürümelerinden de önemli derecede sorumludur. \%30-40 oranında ürünün üreticiden tüketiciye ulaşıncaya kadarki olan sürecindeki hasarlar sebebi ile kullanılamaz duruma gelmektedir (Dalmış ve Kayişoğlu, 2007; Barchi ve ark., 2002).

Hasat ve sonrasında yapılan uygulamalar sırasında gereken özenin gösterilmemesi üründe çeşitli yaralanmaların meydana gelmesine sebep olmaktadır. Başlıca mekanik zedelenme yolları sarsıntı, çarpma, düşme, sürtünme ve sıkışmadır. En fazla görülen yaralanma şekilleri ise delinme ve çizilme (kesilme, yarılma) ile ezilme ve yırtılma (yaprak sebzelerde) şeklinde görülmektedir (Anonim, 2020).

Meyve ve sebzeler dalında iken, solunumda kullandığ 1 besin maddelerini bir taraftan fotosentez yaparak üretmektedir. Ancak, dalından koptuktan sonra artık besin kaynağ kesilmiş olmaktadır. Bu nedenle, solunum sırasında bünyesinde depo ettiği besin maddelerini kullanmaktadır. Bitkinin bu şekilde giderek kendi kendini tüketmesi söz konusu olmaktadır. Sonuç olarak, bitki metabolizması yani solunumu ne kadar hızlı ise, bitki o kadar çabuk yaşlanarak ölmektedir. Hasat işleminden sonra üründeki solunum faaliyetlerinin sürmesi, taze meyve ve sebzelerde hasattan sonra oluşan bozulmaların başlıca nedenidir (Işık, 2002).

Bir oksidasyon olayı olan solunumda, karbonhidratlar havanın oksijeni ile parçalanarak karbondioksit ve suya dönüşmektedir ve enerji açığa çıkmaktadır. Bunların yapılarındaki maddelerin harcanması sonucu, mekanik dirençleri ve mikroorganizmalara dayanıklılıkları azalmakta ve bozulma başlamaktadır. Meyve kabuğunun yaralanması ya da çarpma-düşme sonucu oluşan zedelenmeler ürünün hızla bozulup çürümesine yol açmaktadır. $\mathrm{Bu}$ durum, hasat sonrasında ürün ve kalite kayıplarının artmasına neden olmaktadır (Anonim, 2005).

Domates hasatı sırasında, yanlış hasat yöntemi, hasat sonrasında ise yanlış paketleme ve kötü taşıma koşulları gibi nedenlerle oluşabilecek mekanik hasarlar, oldukça yüksek kayıpların meydana gelmesine sebep olmaktadır. Sıklıkla meydana gelen hasarlar arasında oluşan baskıdan dolayı meyvelerin yüzeyinde düzleşme ve kabukta çatlamalar bulunmaktadır (Şekil 1). Dalmış ve Kayişoğlu (2007) domateslerin kasalar içerisinde maruz kaldıkları kuvvet ve süreye bağlı olarak, fiziko-mekanik dayanımlarının azaldığını, uygulanan mekanik kuvvetlerin süresi arttıkça, domates-sap çarpışmaları sonucu delinme deformasyonlarının artmakta olduğunu belirlemişlerdir.
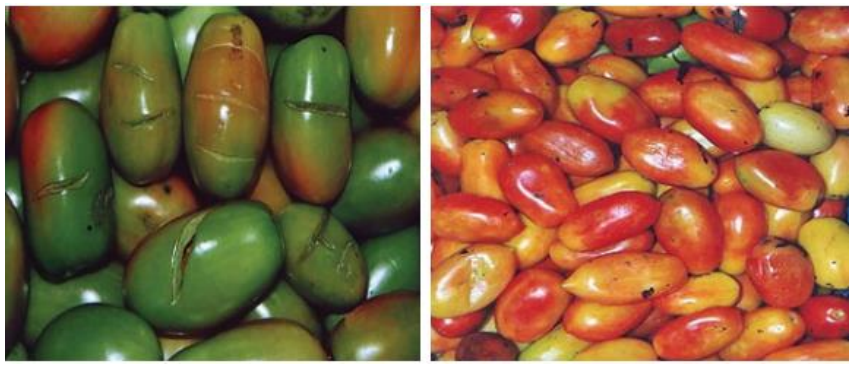

Figure 1. Damages occurred on the surface and stuck parts of the tomato due to improper packaging (Esguerra and Rolle, 2018)

\section{Şekil 1. Uygun olmayan ambalajlama nedeniyle domatesin yüzeyinde ve sıkışan alanlarda oluşan hasarlar (Esguerra ve Rolle, 2018)}

Bu çalışma kapsamında dünyada ve ülkemizde üretim ve tüketimi oldukça yaygın olan domates meyvesi incelenmiştir. Domates hasat sonrasında solunum hızında yükselme olan (klimakterik) ürünlerden birisidir. 
Yürütülen çalışma ile domates meyvesinin hasattan sonraki depolama ve raf ömrüne önemli etkisi olan solunum oranlarının, ortam sıcaklığına ve üründeki zedelenme miktarlarına bağlı olarak değişimleri saptanmıştır. Bu araştırmanın temel amaçları; statik bir ölçme yöntemi kullanılarak ürünlerde hasat sonrası mekanizasyon işlemlerinde oluşabilecek mekanik hasar düzeylerinin ve ortam sıcaklığının; domateste $\mathrm{CO}_{2}$ üretim miktarı üzerine etkilerini belirlemektir. Elde edilen sonuçlardan yararlanılarak ürünlerde solunum oranı ve oluşan kuru madde kayıpları da belirlenmiş̧ir.

\section{Materyal ve Metot}

\subsection{Materyal}

Denemelerde materyal olarak Salkım çeşidi domates (Lycopersicon esculentum) kullanılmışır. Toplam 20 deneme için ağırlıkları 148,39-160,08 $\mathrm{g}$ arasında değişen 10 adet domates alınarak, denemelerin yapılacağı uygun koşullar için muhafaza edilmiştir. Kontrol numunesi olarak herhangi bir etkiye maruz bırakılmayan sağlam meyveler kullanılmışır.

Denemelerde kullanılan domates, oda sıcaklığı ve buzdolabı sıcaklı̆̆ı olmak üzere iki farklı sıcaklık koşulunda denenmiştir. Kontrol örneği olarak hasarsız örnekler ile üzerinde $\mathrm{cm}^{2}$ lik dairesel alan şeklinde kabuğu soyulmuş örnekler ve 10, 20 ve $30 \mathrm{~cm}$ ' den darbe testi uygulanarak mekanik zedelenme oluşturulmuş olan 5 farklı mekanik hasar düzeyine sahip örnekler karş̧laştırılmışır. Araştırmada domatesin karbondioksit salınımı ve kuru madde miktarı arasındaki ilişkilerinin belirlenmesi için de toplam 20 deneme uygulanmıştır.

\subsection{1. Ölçüm sistemleri ve araçları}

$\mathrm{Bu}$ çalı̧̧mada, denemede kullanılacak domatesin yanı sıra darbe düzeneği, hava geçirmeyen cam kaplar, sıcaklık ölçer, dijital karbondioksit ölçüm cihazı, nem ölçer, meyve penetrometresi, buzdolabı ve klima kullanılmıştır.

Ürünlere mekanik hasar uygulayabilmek amacıyla farklı yüksekliklerden çarpma etkisi oluşturulabilecek darbe düzeneği (sarkaç düzeneği) imal edilmiştir. Abedi ve Ahmadi (2013) tarafindan geliştirilmiş düzeneğe benzer şekilde imal edilmiş olan düzeneğe domates örnekleri sabitlenmiştir ve 10,20 ve $30 \mathrm{~cm}$ yüksekliklerden silindir şeklindeki paslanmaz çelikten imal edilmiş olan $300 \mathrm{~g}$ ağırlığındaki sabit bir kütle çarptırılmıştır (Şekil 2). Darbe testleri için meyvenin kendisinin sarkaç üzerinde kütle olarak kullanıldığı bir sistem yerine her ürün için sabit bir kuvvet oluşturabilmek amaciyla literatürlerde de benzer şekilde tasarlanmış olan darbe testinin kullanılması tercih edilmiştir (Abedi ve Ahmadi, 2013).

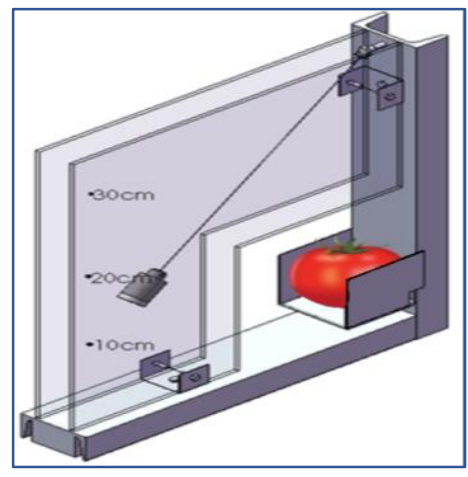

Figure 2. Impact device used in trials

Şekil 2. Denemelerde kullantlan darbe düzeneği

Darbe düzeneğinde sabit kütlenin farklı yüksekliklerden test numunesine çarptırılması ile açığa çıkan farklı miktarlardaki $\mathrm{CO}_{2}$, maksimum 11500 ppm $\mathrm{CO}_{2}$ düzeyine kadar ölçüm yapabilen Testo 650 model $\mathrm{CO}_{2}$ ölçme cihazı ve prob kullanılarak ölçülmüştür. Ölçüm probu cam kap içerisine hava girişi olmayacak şekilde sabitlenmiş ve ölçümler süresince kap içinde tutulmuştur (Şekil 3). Oda sıcaklı̆ğnda 48 saat, soğuk koşulda 24 saat boyunca 
15 dakika aralıkla ölçümler gerçekleştirilmiştir. $\mathrm{CO}_{2}$ ölçme cihazının maksimum $\mathrm{CO}_{2}$ ölçme düzeyinin 11500 ppm olmasından dolayı, $\mathrm{CO}_{2}$ miktarının bu düzeyi aşıp cihazın daha yüksek miktarları ölçemediği durumlarda, $\mathrm{CO}_{2}$ değerleri cihazın ölçebildiği miktar olarak kabul edilmiş olup bu koşullarda ölçümlerin 24 saat yada 48 saat sürmesi beklenmemiştir.

Ürünün solunumu sırasında ortamda oluşan sıcaklık değerinin zamanla değişimini saptamak amacıyla Pico TC-08 sıcaklık ölçme cihazı kullanılmıştır. El tipi dijital nem ölçme cihazıyla nem düzeyinde artış olup olmadığı gözlenmiş, sonuçta ağırlık düzeyindeki değişim AND marka GX-4000 model 0.01g ölçüm hassasiyetine sahip dijital hassas terazi kullanılarak ölçülmüştür. Oda sıcaklığındaki ölçümler sırasında ortam sıcaklığının $22 \pm 2{ }^{\circ} \mathrm{C}$ 'de sabitlenmesi klima kullanılarak sağlanmıştır.

Sıcaklık ve $\mathrm{CO}_{2}$ ölçümlerine paralel olarak ölçümler boyunca örneklerin bulunduğu ortam nemi değerinde değişim olup olmadığının da takip edilebilmesi amacıyla dijital bir nem ölçer kullanılmış ve nem düzeyindeki değişim belli aralıklarla okunarak kaydedilmiştir.

Solunum sebebiyle örneklerde oluşan ağırlık kaybının saptanması için tüm ürünler $\mathrm{CO}_{2}$ ölçümleri yapılmadan önce ve sonra AND marka GX-4000 model 0.01g ölçüm hassasiyetine sahip dijital terazi kullanılarak tartılmıştır.

Verilerinin alınması amacıyla statik bir ölçüm düzeneği kurulmuştur (Şekil 3). Kurulan düzenek ile eş zamanlı olarak sıcaklık, $\mathrm{CO}_{2}$ ve nem düzeyine ilişkin ölçümler yapılmıştır. $2 \pm 2{ }^{\circ} \mathrm{C}$ ' de gerçekleştirilen denemelerde ise ürünün içinde bulunduğu kap bir buzdolabına koyulmuştur.

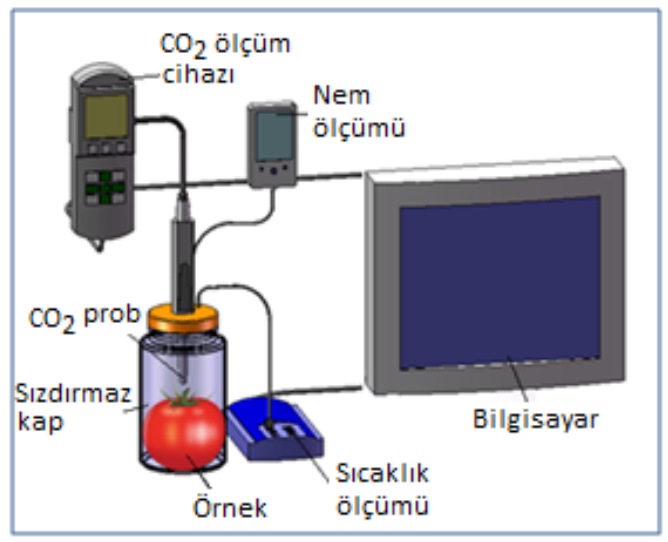

Figure 3. $\mathrm{CO}_{2}$, temperature and relative humidity measurement

\section{Şekil 3. $\mathrm{CO}_{2}$, sıcaklık ve bağıl nem ölçümü}

Deneme materyallerinin sertlikleri, $\mathrm{CO}_{2}$ ve sıcaklık ölçümlerinin tamamlanmasının ardından tartıldıktan ve salınan $\mathrm{CO}_{2}$ 'ye bağlı olarak ağırlık değişimleri saptandıktan sonra meyve penetrometresi kullanılarak ölçülmüştür. Ölçümler, her bir meyvenin çapı boyunca eşit aralıklarla 3 farklı noktasından yapılmıştır ve bu değerlerin ortalaması belirlenmiştir.

\section{2. Yöntem}

\subsection{1. Ürünlerde oluşan zedelenme hacimlerinin saptanması}

Biyolojik materyallere mekanik hasar uygulandıktan sonra oluşan zedelenme Şekil 4'de statik ve dinamik koşullarda elma örneği için verilmiştir. Elmada olduğu gibi aynı şekilde domates için de çeşitli mekanik etkiler sonrasında zedelenen bölgelerde hücre patlaması gerçekleşmektedir. Hücre patlaması olan bölgenin altında kalan kısımdaki hücrelerde ise sıkışma oluşmaktadır. Meyve ve sebzelerde hasardan etkilenen yani hücre patlaması olan zedelenmiş bölgenin hacmi 1 numaralı eşitlik ve ürün yüzeyinden hasar merkezine kadar etkilenmiş hasar derinliği ise 2 numaralı eşitlik kullanılarak hesaplanmıştır (Yurtlu ve Erdoğan, 2005). 
$v=\frac{\pi h}{24}\left(3 d^{2}+4 h^{2}\right)+\frac{\pi x}{24}\left(3 d^{2}+4 x^{2}\right)$

$x=R-\sqrt{R^{2}-\frac{d^{2}}{4}}$

Zedelenme hacminin saptanmasında kullanılmış olan parametreler ise Şekil 4 üzerinde gösterilmiştir (Yurtlu ve Erdoğan, 2005; Aktas ve ark., 2008).

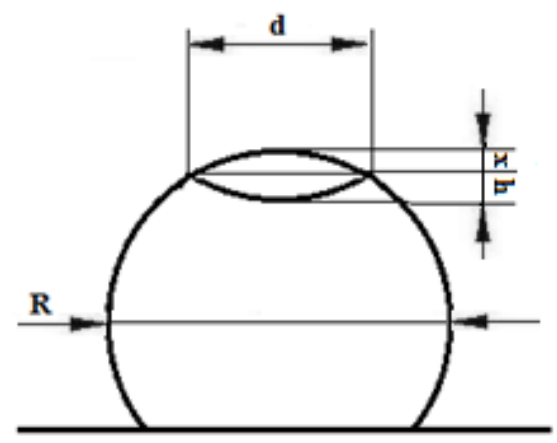

Figure 4. Calculation parameters required for measurement in material after mechanical damage

Şekil 4. Mekanik hasar sonrası materyalde ölçüm için gerekli hesaplama unsurları

Burada;

$\boldsymbol{d}=$ Hasar genişliği $(\mathrm{mm})$,

$R=$ Meyve yarıçapı $(\mathrm{mm})$,

$\boldsymbol{x}=$ Etkilenen bölgenin etki merkezi yukarısında kalan kısmının yüksekliği (mm),

$\boldsymbol{h}=$ Etkilenen bölgenin etki merkezi aşağısında kalan kısmının derinliği (mm),

$\boldsymbol{v}=$ Mekanik hasardan etkilenen toplam bölge hacmidir $\left(\mathrm{mm}^{3}\right)$.

\subsubsection{Solunum oranlarının saptanmast}

Solunum oranı $1 \mathrm{~kg}$ taze ürünün 1 saatte ürettiği gaz miktarı olarak tanımlanmaktadır. Statik sistemler kullanılarak bu oranın belirlenmesi için beş temel faktörün bilinmesi zorunludur (Saltveit, 2007). Bu faktörler;

-kullanılan hava almaz kap hacmi (2000 ml),

-ürün ă̆ırlı̆̆1,

- deneme öncesindeki ( $\mathrm{t}=0$ anında) $\mathrm{CO}_{2}$ miktarı,

-denemenin süresi,

-deneme sonrasındaki $\mathrm{CO}_{2}$ miktarıdır.

Denemeler süresince ppm (Parts per million) olarak ölçülen $\mathrm{CO}_{2}$ konsantrasyonları Eşitlik 3' de verilmiş olan orantı denklemi kullanılarak yüzde değerlerine (\%) dönüştürülmüştür.

$\mathrm{A}=(\mathrm{B} * 100) / 1.000 .000$

Burada;

$\mathrm{A}: \mathrm{CO}_{2}$ miktar1 (\%),

B: $\mathrm{CO}_{2}$ miktarıdır (ppm). 
$\mathrm{CO}_{2}$ gazı üretim oranı olarak da tanımlayabileceğimiz solunum oranı (SO) 4 numaralı eşitlik kullanılarak belirlenmiştir (Saltveit, 2007).

$S O=\frac{S M-\dot{I} M}{M^{*} t} * V$

Bu eşitlikte;

$\mathrm{SO}: \mathrm{CO}_{2}$ gazı cinsinden örneklerin solunum oranı $\left(\mathrm{ml} \mathrm{CO}_{2} \mathrm{~kg}^{-1} \mathrm{~h}^{-1}\right)$,

SM: Son $\mathrm{CO}_{2}$ gazı miktarı (\%),

İM: İlk $\mathrm{CO}_{2}$ gazı miktarı (\%),

V: Sizdırmaz kabın hacmi (ml),

M: Örnek ağırlığ $1(\mathrm{~kg})$,

T: Zamandir (h).

\subsubsection{Kuru madde kaybının saptanmast}

Bitki solunumu, 6 karbonlu şekerin karbondioksit ve suya tamamen oksidasyonu olarak kabul edilir. Bitki solunumunun kimyasal denklemi şu şekilde ifade edilir (Saltveit, 2007):

$\mathrm{C}_{6} \mathrm{H}_{12} \mathrm{O}_{6}+6 \mathrm{O}_{2}+6 \mathrm{H}_{2} \mathrm{O} \rightarrow 12 \mathrm{H}_{2} \mathrm{O}+6 \mathrm{CO}_{2}+673 \mathrm{kcal}(38 \mathrm{ATP})$

$\mathrm{Bu}$ kimyasal denklem (stokiometrik) ifadesi, $\mathrm{CO}_{2}$ üretiminin toplam miktarının yanında kuru madde kaybı için kullanılabilmektedir (Greenhill 1959; Melvin ve Simpson, 1963; Simpson 1961). Solunum sirasında 264 g $\mathrm{CO}_{2}$ üretilirken $180 \mathrm{~g}$ şeker kaybolmaktadır (Saltveit, 2007). Buradan 1 saatteki $1 \mathrm{~kg}$ üründe oluşan kuru madde ağırlık kaybı 5 numaralı eşitlik kullanılarak hesaplanmıştır.

$\mathrm{KMK}=\mathrm{SO} * 10^{-3 *} 68 / 100$

Bu eşitlikte:

KMK: Kuru madde kayb1 $\left(\mathrm{g} \mathrm{kg}^{-1} \mathrm{~h}^{-1}\right)$,

SO: Ürünlerin solunum oran1 $\left(\mathrm{ml} \mathrm{CO}_{2} \mathrm{~kg}^{-1} \mathrm{~h}^{-1}\right)$,

Hesaplanan saatlik kuru madde kaybı kullanılarak depolama periyodu boyunca üründe oluşabilecek kuru madde kaybı (günlük, haftalık vs.) hesaplanabilmektedir.

\subsection{4. İstatistik analizlerin gerçekleştirilmesi}

İki farklı sıcaklıkta saptanmış olan solunum oranları ile mekanik zedelenme, kuru madde kaybı, meyve sertliği arasındaki ilişki ve bu ilişkinin önemli olup olmadığını saptamak amacıyla varyans analizi gerçekleştirilmiştir. Bu analiz yönteminde $\mathrm{CO}_{2}$ üretim miktarı (\%), solunum oranı $\left(\mathrm{ml} \mathrm{CO}_{2} \mathrm{~kg}^{-1} \mathrm{~h}^{-1}\right)$ ve ürünlerde solunum sonrasında oluşan kuru madde kaybı $\left(\mathrm{g} \mathrm{kg}^{-1} \mathrm{~h}^{-1}\right)$ bağımlı değişken; zedelenme hacmi, sıcaklık, meyve sertlik değerleri ise bağımsız değişkenler olarak ele alınmıştır. İstatistik hesaplamaların gerçekleştirilmesinde PASW Statistics 13.0 istatistik programından yararlanılmıştır.

\section{Araştırma Sonuçları ve Tartışma}

\section{1. Örneklerde zedelenme hacimlerine ilişkin sonuçlar}

Tablo 1'de domates örneklerine uygulanan mekanik hasar uygulamaları sonucunda solunum oranlarının saptanmasına yönelik denemelerde kullanılacak olan örneklerde oluşan hasar oranları zedelenme hacmi olarak verilmiştir. 


\section{Tablo 1. Farklı ortam sıcaklıklarında yapılmış olan denemeler için hazırlanmış olan örneklerin zedelenme} hacimleri

Table 1. Damage volumes of samples prepared for trials carried out at different ambient temperatures

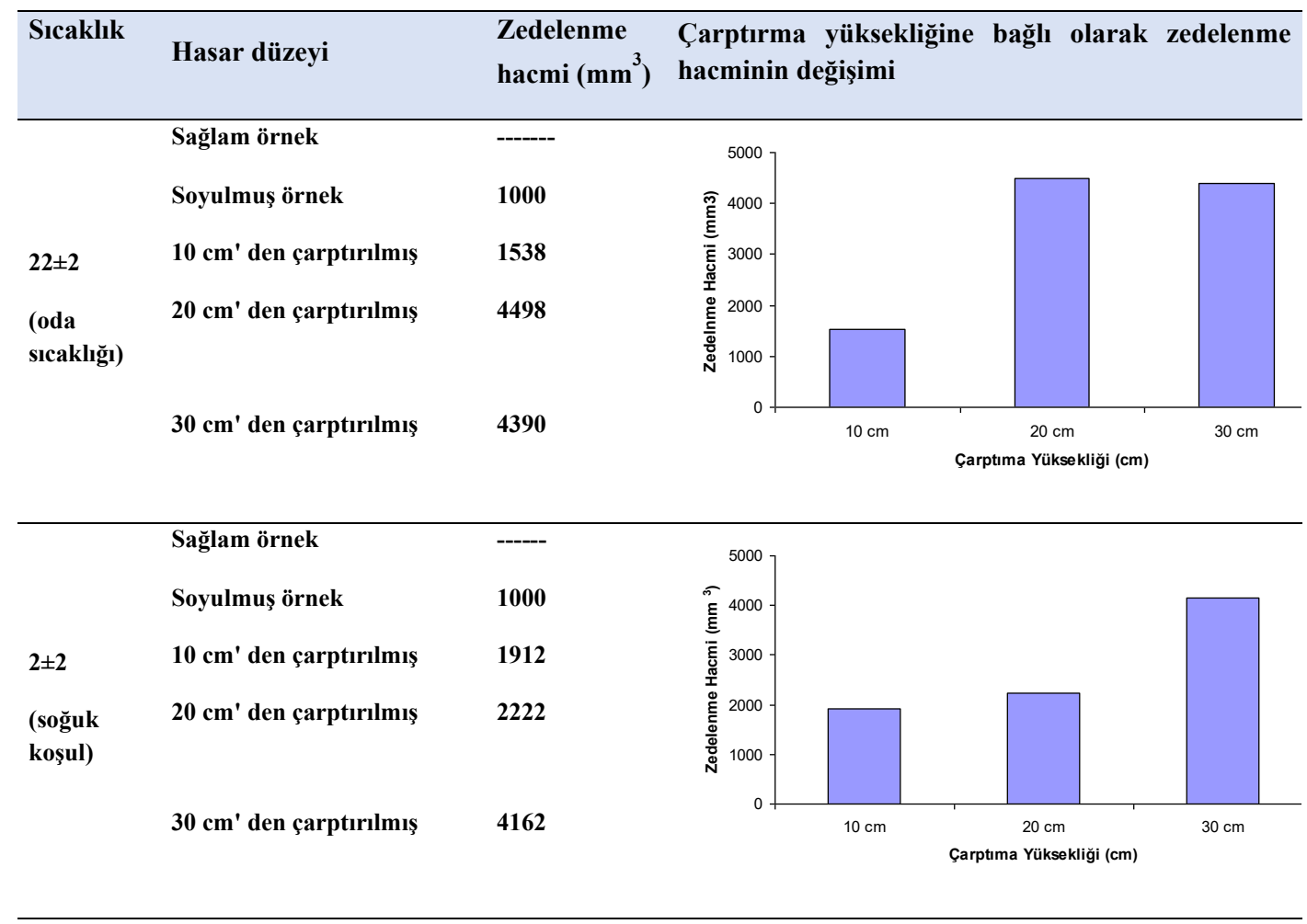

Tablo 1 incelendiğinde darbe yüksekliklerinin artışının ürünlerde oluşan zedelenme hacmini genel olarak arttırdığı belirlenmiştir. Darbe yüksekliklerinin zedelenme hacmi üzerindeki etkisi istatistiksel olarak 0,05 düzeyinde önemli bulunmuştur. Çeşitli tarımsal ürünler için yapılan araştıma sonuçları da bu sonucu desteklemektedir. Örneğin Vursavuş ve Özgüven (2000) farklı elma çeşitleri (Golden Delicious ve Granny Smith) için yaptıkları bir araştırmada pek çok faktör yanında meyve darbe yüksekliğinin maksimum zedelenme çapı ve maksimum zedelenme derinliği üzerinde etkilerinin olup olmadığını araştırmışlardır. Çalışmada ürünleri 30 ve 60 cm'den metal yüzey üzerine düşürerek düşme testlerini gerçekleştirmişlerdir. Araştırma sonucunda her iki çeşit içinde meyve düşme yüksekliğinin zedelenme parametreleri üzerine etkisinin önemli olduğunu saptamışlardır. Aktaş ve ark. (2008) tarafindan gerçekleştirilen ve domatesin zedelenme hassasiyetinin mekanik araçlarla belirlendiği bir başka çalışmada ise $20,30,40$ ve $50 \mathrm{~cm}$ yüksekliklerden darbe etkisi uygulanmış olan domateslerin alt ve yan taraflarında oluşan zedelenme düzeyleri ve zedelenme duyarlılıkları hesaplanmıştır. Zedelenme hacmininde bir göstergesi olan maksimum absorbe edilen enerji değerlerinin düşme yüksekliği ve ürün çarptırma yönüne bağlı olarak önemli oranda değiştĭgi saptanmıştır. Yine Topping ve Luton (1986) elmaların çarpma zedelenmesine olan duyarlılıklarını karşılaştırmışlar, zedelenen bölgelerin çap ve hacimlerinin çarpışma enerjisiyle arttığını, fakat bu artışın çeşide bağlı olarak değiştiğini saptamışlardır.

\subsection{Mekanik hasar uygulamalarının ürünlerde $\mathrm{CO}_{2}$ üretim miktarı üzerine etkilerine ilişkin sonuçlar}

Şekil 5' de oda sıcaklığında ve Şekil 6'da soğuk koşulda farklı mekanik hasar düzeyleri uygulanmış olan domates örneklerinin $\mathrm{CO}_{2}$ üretim miktarlarının değişimi görülmektedir. Şekiller incelendiğinde her iki sıcaklık koşullarında da kontrol örneği olarak alınmış olan hasarsız olan domates örneğinin $\mathrm{CO}_{2}$ üretim miktarlarının diğer örneklerinkine kıyasla oldukça düşük olduğu görülmektedir. Şekil 5 ve 6'dan da anlaşıldığı gibi ortam sıcaklığının yükselmesi ile ürünün ürettiği $\mathrm{CO}_{2}$ miktarında oldukça büyük bir artış olmuştur. Ayrıca oda sıcaklığı koşullarında 
bu artışın çok daha kısa sürede gerçekleştiği saptanmıştır. Ortam sıcaklığ $2 \pm 2{ }^{\circ} \mathrm{C}$ iken ortamdaki $\mathrm{CO}_{2}$ oranı sağlam domates örnekleri için 24 saatin sonunda \%0.49'dan \%3.95'e yükselmiştir. Bu oran $22 \pm 2{ }^{\circ} \mathrm{C}$ ' de tutulan domates örnekleri için \%0.49'dan sadece 14 saat sonunda \%11.53'e yükselmiştir. $2 \pm 2{ }^{\circ} \mathrm{C}$ ortam sıcaklığ 1 koşulunda bütün hasarlı örneklerde $\mathrm{CO}_{2}$ üretim miktarı sağlam örneklerinkine göre oldukça yüksektir fakat mekanik hasardan dolayı $\mathrm{CO}_{2}$ üretimindeki artış hemen hemen aynı düzeyde olmuştur (Şekil 5). Oda sıcaklığı koşulunda domates örneklerinin $\mathrm{CO}_{2}$ üretimi üzerine farklı mekanik hasar düzeylerinin etkisinin istatistiksel olarak 0,05 düzeyinde, soğuk hava koşulundaki örneklerin $\mathrm{CO}_{2}$ üretimi üzerine farklı mekanik hasar düzeylerinin etkisi ise istatistiksel olarak 0,01 önemli bulunmuştur. Ortam sıcaklığının $\mathrm{CO}_{2}$ üretim miktarı üzerine etkisinin ise 0,01 düzeyinde önemli olduğu saptanmıştır.

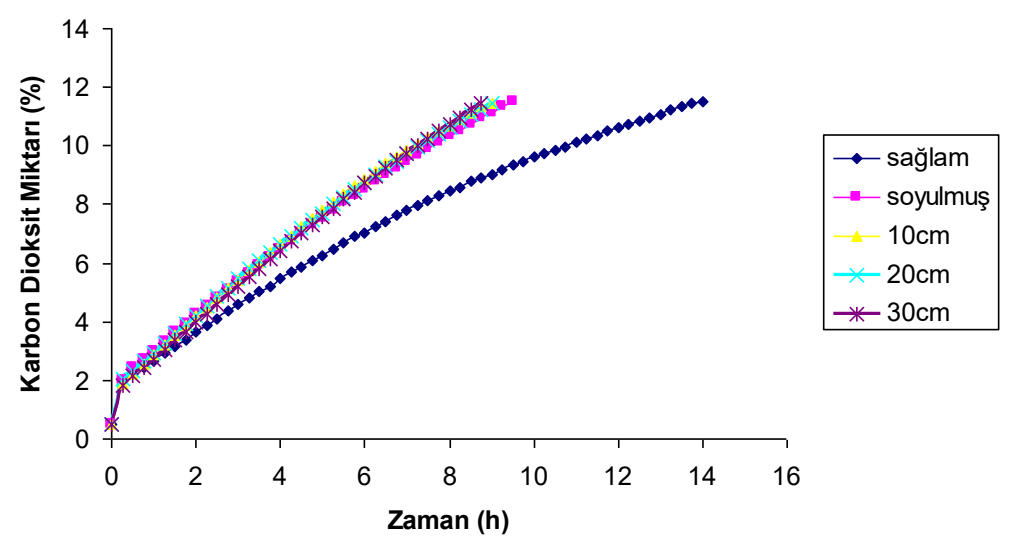

Figure 5. Effect of mechanical damage level on $\mathrm{CO}_{2}$ production of tomato at room temperature $\left(22 \pm 2{ }^{\circ} \mathrm{C}\right)$ Şekil 5. Oda sıcaklı̆̆ı koşulunda $\left(22 \pm 2{ }^{\circ} \mathrm{C}\right)$ mekanik hasar düzeyinin domatesin $\mathrm{CO}_{2}$ üretim miktarına etkisi

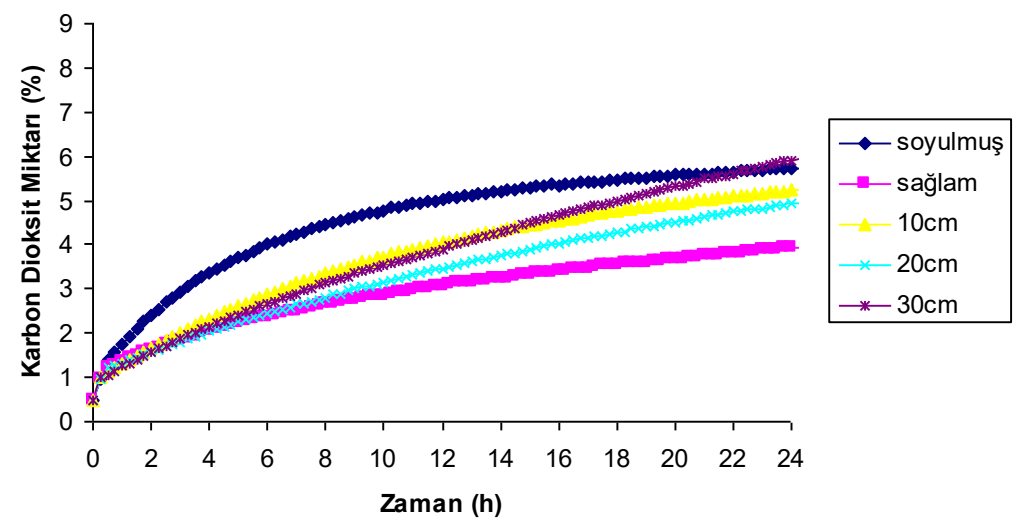

Figure 6. Effect of mechanical damage level on $\mathrm{CO}_{2}$ production of tomato in cold weather $\left(2 \pm 2{ }^{\circ} \mathrm{C}\right)$

Şekil 6. Soğuk hava koşulunda $\left(2 \pm 2{ }^{\circ} \mathrm{C}\right)$ mekanik hasar düzeyinin domatesin $\mathrm{CO}_{2}$ üretim miktarına etkisi

Elde edilen bu sonuçlara göre genel olarak, domates için sıcaklık ve mekanik hasar düzeyi arttıkça solunumun hızlandığı ve solunum sonucunda açığa çıkan $\mathrm{CO}_{2}$ düzeylerinde artış olduğu saptanmıştır. Benzer şekilde Tetteh ve ark. (2004)' da meyvelerde sıcaklık arttıkça solunumun arttığını ve böylelikle olgunlaşmanın yavaşlayarak ürün kalitesinin azaldığını belirtmiş, buna bağlı olarak ürünlerin hasat sonrasında çiftliklerde portatif soğutucularda korunmasının, tazeliği korumak için etkili olduğu sonucuna varmışlardır. Bu araştırmada da sıcaklık ve solunum ilişkisi, Tetteh ve ark. (2004)' nın bu sonucuyla örtüşmektedir. Aynı durumu destekleyen bir diğer araştırma ise Kraus ve ark. (1999) tarafından kaba yemin solunumu üzerine zedelenmenin etkisi üzerine yapılmıştır. Mekanik etki altında kaba yem örneklerinin muhafaza edildiği sıcaklığın $31^{\circ} \mathrm{C}$ 'den $11^{\circ} \mathrm{C}$ 'ye düşürülmesi, kontrol 
örneklerinin solunum oranlarını yaklaşık \%50 azaltmış ve solunumdan dolayı kaybolan toplam kuru madde miktarı tüm deneylerde 48 saatin sonunda $\% 3$ 'ten daha az olarak tespit edilmiştir.

Ürünlerde solunumun buzdolabı ortamında daha düşük $\mathrm{CO}_{2}$ düzeylerine çıkabildiği tespit edilmiş ve bu durum Boyette ve ark. (1993)'nın çayüzümü bitkisinde (Vaccinium sp.) hasat sonrasında soğukta bekletme ve depolama boyunca dayanıklılık üzerine yaptıkları araştırmayla da uyumlu bulunmuştur. Araştırmaya göre, deneye alınan meyvelerin hasat sonrasında soğukta bekletildikçe tazeliklerinin muhafaza edildiği tespit edilmiştir. $\mathrm{CO}_{2}$ üretiminin tazeliğe yönelik olarak etken bir faktör olması açısından çalş̧mamız bu sonuçla paralellik arz etmektedir.

\subsection{Mekanik hasar uygulamalarının ürünlerde solunum oranına etkilerine ilişkin sonuçlar}

Örneklerin solunum oranları statik koşul ölçüm metotlarına uygun olarak ilk 15 dakikalık periyot için hesaplanmıştır. Oda koşullarında ve soğuk koşulda domates örneklerinin solunum oranlarının $\left(\mathrm{CO}_{2}\right.$ üretim oranları) üründe oluşturulan hasar düzeylerine bağlı olarak değişimi Şekil 7'de görülmektedir.

Şekil 7 incelendiğinde kabuğu soyulmuş olan örneklerin hem oda koşullarında hem de soğuk ortam koşullarında solunum oranlarının diğer örneklerinkine kıyasla çok daha yüksek olduğu bunu $30 \mathrm{~cm}$ yüksekten çarptırılan örneklerin izlediği anlaşılmıştır. Hem ortam sıcaklığının hem de zedelenme düzeylerinin solunum oranı üzerine etkilerinin 0,01 düzeyinde önemli olduğu saptanmıştır.

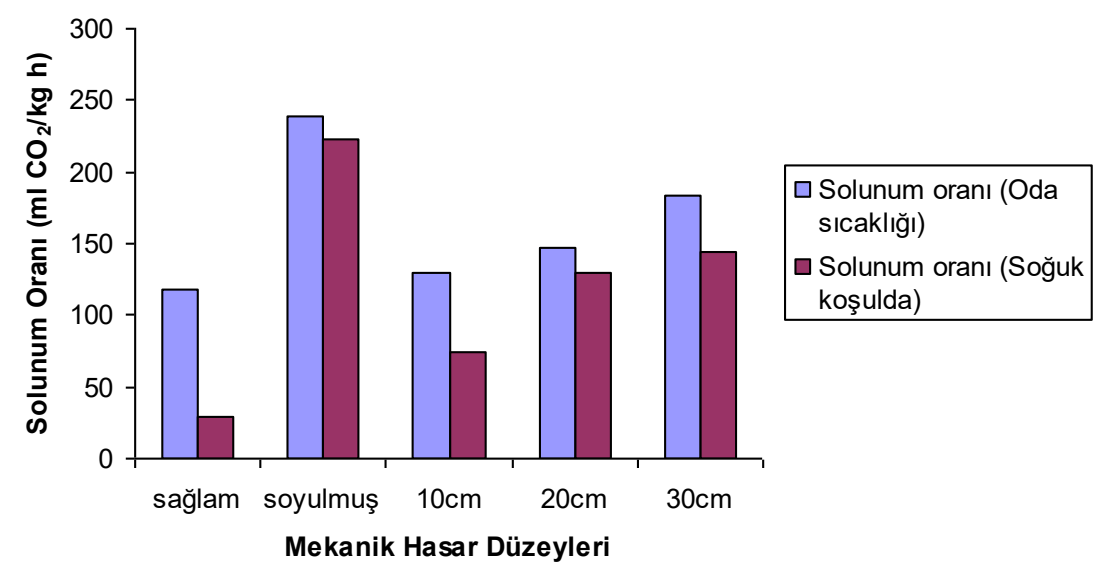

Figure 7. Changes in respiration rate depend on ambient temperature and mechanical damage level in tomato samples

Şekil 7. Domates örneklerinde solunum oranının ortam sıcaklığı ve mekanik hasar düzeyine bağlı olarak değişimimi

\subsection{Mekanik hasar uygulamalarının ürünlerde kuru madde kaybı üzerine etkilerine ilişkin sonuçlar}

Kuru madde kayıplarııın $\left(\mathrm{g} \mathrm{kg}^{-1} \mathrm{~h}^{-1}\right)$ iki farklı sıcaklık koşulunda mekanik hasar düzeyine bağlı olarak nasıl değiştiği domates içi Şekil $8^{\prime}$ de görülmektedir. Solunum oranlarına paralel olarak maksimum kuru madde kaybının kabuğu soyulmuş olan örneklerde oluştuğu ve bunu sırasıyla $30 \mathrm{~cm}$ yükseklikten çarptırılan, $20 \mathrm{~cm}$ yükseklikten çarptırılan ve $10 \mathrm{~cm}$ yükseklikten çarptırılan örneklerin takip ettiği saptanmıştır. En düşük kuru madde kaybı ise herhangi bir mekanik zarara uğramamış olan örneklerde olmuştur. Örneklerde oluşan kuru madde kayıpların soğuk hava koşulunda dahi oldukça yüksek değerlerde gerçekleştiği anlaşılmaktadır. 


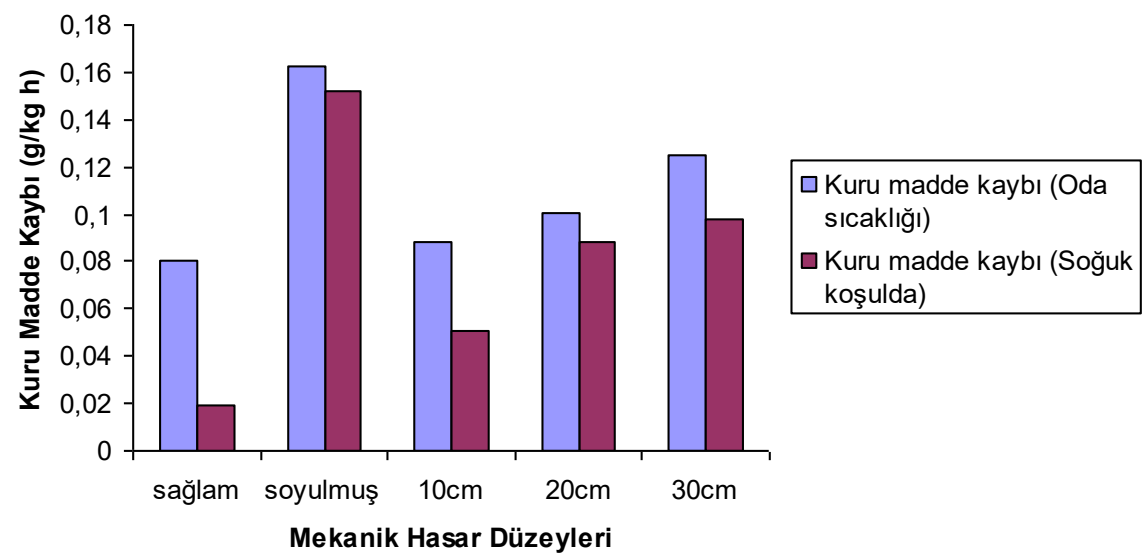

Figure 8. The effect of mechanical damage level on dry matter loss of tomato samples under room temperature condition $\left(22 \pm 2{ }^{\circ} \mathrm{C}\right)$ and cold condition $\left(2 \pm 1{ }^{\circ} \mathrm{C}\right)$

\section{Şekil 8. Oda sıcaklığı koşulunda $\left(22 \pm 2{ }^{\circ} \mathrm{C}\right)$ ve soğuk ortam koşulunda $\left(2 \pm 1{ }^{\circ} \mathrm{C}\right)$ mekanik hasar düzeyinin domates örneklerinin kuru madde kaybına etkisi}

Zedelenme düzeyi, ortam sıcaklığının solunum sırasında ürünlerde oluşan kuru madde kaybı üzerine etkisi 0,01 düzeyinde önemli bulunmuştur.

\section{5. Örneklerde solunum denemeleri sonrasında oluşan ağırlık kaybı ve meyve eti sertliğindeki değişimlere} ilişkin sonuçlar

Tablo 2'de uygulanan mekanik hasar uygulamaları sonucunda solunum oranları saptanmış olan örneklerde oluşan ağırlık kaybı ve meyve eti sertliğinde oluşan değişimler görülmektedir.

Tablo 2. Ağırlık kaybı ve meyve sertliğinin değişimi (sağlam örneklerin ortalama sertlik değerleri: 5.8 kgf)

Table 2. Changes in weight loss and fruit hardness (average hardness values of firm samples: $5.8 \mathrm{kgf}$ )

\begin{tabular}{cllc}
\hline Sıcaklık & \multicolumn{1}{c}{ Hasar düzeyi } & A ğırlık kaybı (g) & $\begin{array}{c}\text { Meyve eti sertliği } \\
\text { (kgf) }\end{array}$ \\
\hline $22 \pm 2($ oda & Sağlam domates & 0.06 & 11.484 \\
koşulu) & Kabuğu soyulmuş & 0.36 & 5.393 \\
& 10 cm'den çarptırılmış & 0.14 & 5.57 \\
& 20 cm'den çarptırılmış & 0.15 & 4.32 \\
& 30 cm'den çarptırılmış & 0.12 & 8.668 \\
\hline $2 \pm 2$ (soğuk & Sağlam domates & 0.08 & 7.954 \\
hava koşulu) & Kabuğu soyulmuş & 0.28 & 4.654 \\
& 10 cm'den çarptırılmış & 0.09 & 5.353 \\
& 20 cm'den çarptırılmış & 0.8 & 9.11 \\
& 30 cm'den çarptırılmış & 0.5 & 7.255 \\
\hline
\end{tabular}

Ağırlık kayıpları göz önünde bulundurulduğunda, tüm deneme materyallerinde ölçümler öncesi ve sonrası arasında en büyük ağırlık kayıplarının da diğer tüm sonuçlara paralel olarak kabuğu soyulan meyvelerde olduğu görülmektedir. Ağırlık kayıpları, genel olarak solunum devam ettikçe açık bir şekilde gözlemlenmiştir. 
Sertlik ölçümleri ve hasarla ortaya çıkan deformasyonla ilgili olarak, Chen ve ark. (1987), düşürme testlerinde ortaya çıkabilecek zedelenmelerin belirlenmesi için hazırladıkları deney cihazını kullanmışlar ve çelik yüzeyler üzerine farklı yüksekliklerden elmaları düşürmüşlerdir. Meyvelerde oluşan farklı zedelenme düzeylerinin meyve çeşidine ve olgunluğa bağlı olarak değiştiğini, meyve sertliği ile zedelenmenin ters orantılı olduğunu tespit etmişlerdir. Bu sonuçlara paralel olarak Tablo 2 incelendiğinde oda sıcaklığındaki meyvelerde en yüksek sertliğin sağlam örnekte olduğu gözlemlenmiştir. Mekanik hasar uygulanan ve kabuğu soyulan ürünlerde ise bariz bir sertlik kaybı olduğu gözlenmektedir fakat bu kayıplar, uygulanan hasar düzeyine oranla düzenli bir dağılım sergilememektedir. Soğuk hava koşulunda ölçümleri yapılan ürünlerde ise sertlik ölçümlerinin düzenli bir dağılım arz etmediği, oda sıcaklıklarında yapılan ölçümlere göre daha kararsız olduğu saptanmıştır.

Yapılan istatistiksel analizler sonucunda ürünlerdeki ağırlık kaybı-solunum oranı ve meyve eti sertliği-solunum oranı arasındaki ilişkinin önemsiz olduğu saptanmıştır $(\mathrm{P}>0,01)$.

\section{Sonuç}

Bir tarımsal ürünün metabolizması yani solunumu ne kadar hızlı ise raf ömrünün de o kadar kısa olması nedeniyle ürünün hasattan sonraki depolama ömrünü uzatmak için en başta solunumunun yavaşlatılması gerekmektedir. Özellikle depolama sırasında solunumdan kaynaklanan kuru madde kaybının üründe oluşan zedelenme düzeyi ve ortam sıcaklığına bağlı olarak saptandığı bu çalışmadan elde dilen sonuçlar; ürünlerin farklı ortam koşullarındaki depolama ömürlerinin tahmin edilebilmesine kaynak sağlaması açısından ve hasat sonrası işlemler özellikle de depolama işlemi ve ayrıca hasat sonrasında mekanizasyon uygulamaları sırasında üründe oluşabilecek mekanik zedelenmelerin bu kayıplar üzerine etkisi üzerine de veri tabanı oluşturması yönünden yararlı olacaktır. Ayrıca ileride yapılabilecek olan ve depolanan üründe zamanla oluşacak olan bozulmalar (yumuşama, küflenme vb.) sırasındaki kuru madde düzeylerinin deneysel olarak saptanarak o ürünlerin raf ömrünün ampirik olarak tahmin edilebileceği modellerin geliştirilmesine de temel olacaktır. 


\section{Kaynakça}

Abedi, G., Ahmadi, E. (2013). Design and evaluation a pendulum device to study postharvest mechanical damage in fruits: bruise modeling of red delicious apple. Australian Journal of Crop Science (AJCS). 7(7):962-968.

Aktas, T., Polat R., Atay, U. (2008). Mechanical properties and bruise susceptibility of tomatoes related to impact direction and drop-height. The Philippine Agricultural Scientist. 91(2): 180-186.

Anonim (2005). Meyvelerin bozulmasını önleyici bir artık: şeker pancarı küspesi. (http://web.firat.edu.tr/firathaber/sayilar/180/6.pdf). (Erişim tarihi: 16.06.2020).

Anonim (2020). Ürün kalitesi ve depolama ömrü üzerine etkili hasat sonrası faktörler, (https://www.sorhocam.com/konu.asp?sid=1124\&meyve-ve-sebzelerin-muhafazasi.html/). (Erişim tarihi: 23.03.2020).

Barchi, G.L., Berardinelli, A., Guarnieri, A., Ragni, L., Totaro Fila, C. (2002). Damage to loquasts by vibration- simulating intra-state transport. Biosystems Engineering. 82: 305-312.

Boyette M. D., Estes, E.A., Mainland, C. M., Cline, W. O. (1993). Postharvest Handling and Cooling of Blueberries. Publication No. AG 4137. Raleigh, N.C.: North Carolina State University, Cooperative Extension Service.

Chen, P., Ruiz, M., Lu, F., Kader, A. A. (1987). Study of impact and compression damage on asion pears. Transaction of the ASAE. 30(4): 1193-1197.

Dalmış, İ. S., Kayişoğlu, B. (2007). Domates kasalarında titreşim etkisiyle oluşan eksenel kuvvetlerin belirlenmesi için prototip ölçüm setinin geliştirilmesi. Tarım Makinaları Bilimi Dergisi. 3(3): 195-204.

Esguerra, E. B., Rolle, R. (2018). Post-harvest Management of Tomato for Quality and Safety Assurance. Guidance for horticultural supply chain stakeholders. Food and Agriculture Organization of The United Nations. Rome.

Greenhill, W. L. (1959). The respiration drift on harvested pasture plants during drying. Journal of the Science of Food and Agriculture. 10: 495-501.

Işık, E. (2002). Ürün İşleme Makinaları. Uludağ Üniversitesi Ziraat Fakültesi Ders Notu No: 92, Uludağ Üniversitesi Ziraat Fakültesi Tarım Makinaları Bölümü, Bursa. s. 50-56.

Kraus, T. J., Muck, R. E., Koegel, R. G. (1999). Effect of maceration on repiration of alfalfa. Transactions of the ASAE. 42(1): 5-10.

Melvin, J. F., Simpson, B. (1963). Chemical changes and respiratory drift during the air drying of ryegrass. Journal of the Science of Food and Agriculture. 14: 228-234.

Nelson, C. W., Mohsenin, N. N. (1968). Maximum allowable static and dynamic loads and effect of temperature for mechanical injury in apples. Journal of Agricultural Engineering Research. 13(4): 305-317.

Saltveit, M. E., Gross, K. C., Wang, C. Y., Saltveit, M. (2007). Respiratory Metabolism. In Agricultural handbook number 66: The commercial storage of fruits, vegetables, and florist and nursery stocks. US Dept. Agr., Washington, DC.

Simpson, B. (1961). Effect of crushing on the respiratory drift of pasture plants during drying. Journal of the Science of Food and Agriculture. 12: $706-712$

Tetteh, M. K., Prussia, S. E., NeSmith, D. S., Verma, B. P., Aggarwal, D. (2004). Modeling blueberry firmness and mass loss during cooling delays and storage. Transactions of the ASAE.47(4): 1121-1127.

Topping, A. J., Luton, M. T. (1986). Cultivar differences in the bruising of english apples. Journal of Horticultural Science. 61(1):9-13.

Vursavuş, K., Özgüven, F. (2000). Çarpma durumunda elmanın fiziko-geometrik özelliklerinin mekanik zedelenme üzerindeki etkisinin araştırılması. Tarımsal Mekanizasyon 19. Ulusal Kongresi (1-2 Haziran 2000, Erzurum) Bildirileri, 489-494.

Yurtlu, Y. B., Erdoğan, D. (2005). Domates çeșitlerinde depolama süresinin bazı mekanik özelliklere etkisinin incelenmesi. Ankara Üniversitesi Ziraat Fakültesi Tarım Bilimleri Dergisi . 11(2) 201-206. 